\title{
Cardio retinometry exposes pharmaco-medical secrets, and the UK's NHS as a murderous, money making parasite infesting UK and world health
}

\begin{abstract}
Introduction: Extreme language justified by personal knowledge of U.K. National Health Service corruption, being the Optometrist who discovered retinal confirmation of Nobellist Linus Pauling's \& Rath's CHD hypothesis that vitamin C reverses arterial disease; immediately threatened and eventually ordered by the NHS to keep it secret, I had the responsibility and obligation to verify it and inform the public. Astonishingly, the peer-reviewed journals and newspapers colluded preventing this. Coronary heart disease (CHD) reversal, is not easily seen ophthalmoscopically or by film photography. Electronically enhanced image magnification, and sequential time-lapse comparability reveals microscopically measurable changes. Retinal vasculature is an accepted surrogate outcome predictor of hypertension, CHD, atheroma, thrombosis, and stroke together killing $>66 \%$.

Method: The author published 700 Vitamin $C$ Secrets textbook ridiculing medicine Textbooks Baynes \& Dominiczak's, Biochemistry and Guyton \& Hall's Physiology were researched: Thousands of precisely overlaid, identically matched, flicker alternated sequential retinal images were investigated for cumulative $1 \%$ annual increases or decreases.

Results: Textbooks guilty of expunging sodium ascorbate and downgrading scurvy. Majority of patients convinced; testifed to consistently vitamin $\mathrm{C}$ related disappearing arteriolar "reflex" atheroma, contrasting "normal," "age related," increase, evidentially not "reflex" but Hollenhorst type intraluminal plaque and consequently potentially fatal heart attacks in plain sight. Rath states that if growth of coronary artery deposits is stopped, no heart attack would occur.

Conclusion: Millions have suffered medically imposed heart disease; fraudulent CHD surgical countermeasures; stents: bypasses; strokes; paralysis; fatal 2\% X-Ray induced cancers; houses mortgaged for heart bypasses; early death; families destroyed. MedicoPharmaceutical profits incompatible with honest medical practise. An incomprehensibly vast human global demographic distortion unfolded of catastrophe, discounting 80years of Western Medicine's "advances," ethics journals, antibiotics, myriad "treatments," and "management," opportunities, medically devised and created. Author introduces additional Doctor of CardioRetinometry (DCardioRet) qualification course reducing premature heart deaths by $98 \%$, restoring confidence.
\end{abstract}

Volume 8 Issue 4 - 2017

Sydney J Bush

Institute of CardioRetinometry Skidby House, England

Correspondence: Sydney J Bush, Skidby House. Head of Faculty of Optometry \& CardioRetinometry, Cosmopolitan University, Director Institute of CardioRetinometry, Skidby, England HUI6 5TF, UK, Email sydneybush@hotmail.com

Received: March 29, 2017| Published: March 31, 2017

\section{Keywords and new terminology}

A new language has developed from CardioRetinometry ${ }^{\circledR} 40$ new terms await the student. These will have to wait for a further paper. Briefly, denial of the revsibility of arterial disease had led to conspiracy to avoid terminology to suggest its possibility. Logically atheroma dissolving would perhaps be "atherolysis." But search Google for atherolysis and you are questioned "did you mean Arthrolysis" because the logical medical term has been suppressed. Only joints can relate to this sounding term.

\section{Additional degree necessary for family doctors}

The new course for the degree of Doctor of CardioRetinometry holds many surprises for the physician who has been in practice for some years. Many mysteries are explained. Childhood illnesses, and hundreds of unexpected explanations will start family doctors looking with fresh eyes at their patients. Some will prefer to withdraw entirely from family practice to concentrate on prevention destined to greatly reduce the work of the family doctor.

\section{Definition of western medicine}

This has actually become "Alternative Medicine." True Medicine is Orthomolecular. Medicine became diagnosis and treatment (but ideally not the $100 \%$ cure that would result in supreme good health) of the fifty or more profitable deficiency diseases of occult scurvy, by the employment of preferably patentable vitamin C substitutes, and denial of natural cures with mind controlling potential of television and news media, to change public perceptions of e.g. cholesterol, mass medication of water supplies and vaccines for the alleged prevention of these same diseases curable by vitamin $\mathrm{C}$.

\section{Definition of pharmacy}

Pharmacy is the many times convicted criminal organisation, profiting from cartels to deny access to cheap vitamins, the supply of vitamins, the legal contamination of vitamins by toxic sweeteners, and a general limitation internationally by means of the Codex Alimentarius, together with control of information regarding the fifty or more preventable but most profitable diseases at risk from widespread knowledge of the health benefits vitamin C's prevention of occult scurvy. It specialises in substituted drugs ideally creating 
dependency and the need for drugs to counter the unwanted side effects of other drugs, and directs a proportion of its resulting wealth from drugs (before their compulsory withdrawal in many cases e.g. some statins, Vioxx, Ibuprofen, and damaging promises regarding the heart benefits of Aspirin and useless cough medicines) to control of medical schools' curricula, peer reviewed journals and research teams. All research funding is directed so far as possible to preventing perfect health and misleading the public e.g. with false information using synthetically weakened vitamin $\mathrm{E}$ and alleged dangers of vitamin $\mathrm{C}$ and blind alleys where esoteric argument won't damage profits.

\section{Mind control -"the rational skepticism" website $^{\prime}$}

The best form of defence is attack: In order to keep the advantage, PharmacoMedicine uses the media in subtle ways. But website Rational Skepticism attempts the boldest populist "de-bunking" by white hot fury vented against vitamin $\mathrm{C}$ evoked by mention of "PseudoScience" i.e. CardioRetinometry. Pharmacologists Dr. Steve Hickey and Dr. H. Roberts $^{2}$ in the chapter of their RDA book devoted to vitamin $\mathrm{C}$ and CardioRetinometry concluded, "Objections to this work carry little weight, as such replication could produce a definitive refutation". They state this after suggesting "Bush reports a consistent and large effect, which is easily replicable in a short period by an independent experimenter at low cost." The ability other scientists to "debunk" without having done so is ignored.

\section{Introduction}

Criminals do not advertise their wrongdoing. Tricksters keep their tricks secret. They take great care to appear legal and avoid risk of indictment. When vitamin $\mathrm{C}$ appeared on the horizon, the first to panic regarding loss of profits was undoubtedly we might assume, the medical profession. At that time doctors were herbalists and pharmacy was honest, working on improving disinfectants, bacteriostats like the sulphonamides, and anaesthetics. Antihistamines and the new classes of drugs followed.

Obviously by 1958 the pharmaceutical industry was increasingly alarmed that its work in producing more and better antibiotics was being threatened by increasing knowledge of vitamin $C^{\prime}$ 's antibacterial power both orally and intravenously. Much of this panic was due to Dr Frederick R. Klenner ${ }^{3-7}$ MD., FCCP, Magna cum Laudae, a gifted physician who was the first to prove the viricidal ability of ascorbate. His papers were ignored and his reception at the American Medical Association was frosty when he described his cure of 60 Polio cases without paralysis.

It is reasonable to assume that, in the 10years between Klenner's life changing findings and 1958, that pharmaco-medicine's joint interests lay in devising a response to the threat, before investing large sums on more antibiotics that might find no market. To this end, is it surprising to discover that not a single abstract to a Klenner paper is published on the PubMed website. But Dr. Lendon Smith ${ }^{9}$ collected them into a booklet for publication.

\section{Emptying hospitals}

The scale of the problem of useless medicine avoided by Vitamin C: This Optometrist cannot get a hearing. Aloof medicine scoffs. Politicians follow suit. Politics - UK Old Age pensions suggest it is policy to prevent life extension? It is unlikely that much further investigation was needed. Klenner revealed too much after consulting with Jungeblut about poliovirus and ascorbic acid. First came in
1941 Patterson's, ${ }^{10}$ aortic scurvy finding, Then Klenner's incredible discoveries that could empty hospitals today of all infections, coronary heart, allergic and slow to heal cases. Then came then Willis ${ }^{\prime 1-18}$ reversal of coronary arterial disease, after much work with Guinea Pigs successfully treated with vitamin $\mathrm{C}$, and the mass of evidence building in Klenner's practice relating to actual cures for so many diseases it is best to list some of them. It is a short list. A longer list is in 700 Vitamin C Secrets.

\section{Arthritis}

2. Bacterial infection of all types often accelerated by antibiotics. MRSA was unknown at that time but is cured from personal experience of people taking y advice on the Internet as I published in Rapid Responses in the BMJ (Rapid Response to Biant)

3. Basal cell carcinoma (small with $30 \%$ ointment - today liposomal would be better?)

4. Burns infection prevented (Specific for pseudomonas)

5. Cancer of bladder. (He quotes Schlegel's (Tulane University) use of ascorbic acid (Lendon Smith) Metabolites fail to develop in ascorbate rich urine. (not wasted!)

6. Cancers. Combination treatment with bitter almonds to taste the cyanide, the poisoning prevented by the ascorbate, the cyanide kills the cancer cells. Author has tried this to prevent prostatic cancer, His monster 360gram gland was eventually removed cancer free. The normal gland removed weighs 60 grams.

Ascorbic acid is the antidote to cyanide toxaemia.

7. Carbon monoxide "flash oxidised almost immediate recovery instead of death or lifelong damage under the UK's NHS. (Why isn't ascorbate in fire trucks?)

8. Chicken Pox - No need for vaccines

9. Cholesterol reduces (excretion in the bile is accelerated - see Ginter for support)

10. CNS hypertension reduced

11. Corneal ulcers, Gangrene,

12. Cystitis

13. Duodenal ulcer

14. Encephalitis, Viral and bacterial He maintained they started with colds,

15. Glaucoma relieved and cured (later confirmed in 1966 by Virno then Bietti)

16. Heavy metal poisoning eliminated by ascorbate

17. Herpes Simple

18. Herpes Zoster

19. Hypermennhorrhoea

20. Insectidide poisonng countered by ascorbate.

21. Lead poisoning prevented and cured (caught early)

22. Leg Cramps,

23. Leukaemia,

24. Malaria 


\section{Measles (Hard)}

26. Miscarriage,

\section{Mononucleosis}

28. Mumps - no need for vaccines

29. Myelocytic leukemia(prolonged daily intravenous infusions 100 to 300 grams)

30. Pancreatitis (acute and chronic)

31. Paraquat poisoning would be in this list if it had been known then. The first case of successful cure was by ascorbate. (Matkovics et al. 1980)

\section{Peptic ulcer}

33. Pneumonia viral and bacterial,

34. Poliomyelitis,

\section{Postoperative sickness}

36. Postpartum haemorrhage,

37. Pregnancy aided. No still births. Neonates protected.

38. Pseudomonas infection cured and prevented. (Author's amazing personal experience)

39. Radiation sickness

40. Rheumatic disease,

41. Rheumatic fever

42. Rocky Mountain Spotted fever

43. Scarlet fever,

44. Schizophrenuia (work supported by Hoffer)

45. Septicaemia. (newspapers almost weekly report child deaths under the NHS)

46. SIDS,

47. Snakebite antidote, (He abandoned antitoxin use)

48. Tetanus,

49. Thrombosis,

50. Toxins neutralised.

51. Tuberculosis

52. Urethritis

53. Viral fevers of all types

54. Whooping cough with one exception these are extracted from Dr Lendon Smith's list.

Sabin $^{8}$ tried to discredit Jungebut's research into ascorbic acid to promote his vaccine. The major pharmaceutical companies had very good reason to be increasingly worried. It is clear from these papers that in the 1950s many were impressed with vitamin C. Sabin, in the same lab was deeply worried about devaluation of his work.

This list shows that without the drain on the NHS of unnecessary heart bypass operations and stroke represent perhaps $30 \%$ of all the inpatient costs, this might be enough to reduce income tax or pay off the National Debt? Corresponding USA benefits are obvious.
Was there a conspiracy? Yes. The graph proves it?: Rumour had it that a meeting of major importance took place, probably in the USA, between representatives of medicine and their medical counterparts employed in pharmacy. I would date it at 1957 from the graph. If they were established physicians of rank, e.g. serving on the UK's General Medical Council, they are unlikely to have been under forty years of age. The meeting, if in 1957 would put them at 60years older now, the youngest being 100 . If so then probably most of those at that meeting are now dead.

It is said that they were told by pharmaceutical doctors "You want us to develop new antibiotics and all the increasingly hi-tech equipment that modern medicine is going to need. You cannot have these things and continue to beat the vitamin C drum!"

If that is so, and from a commercial viewpoint, it makes sound business sense, then we should be able to find evidence that points to such a meeting. Can we expect to find the evidence in individual papers in the archive of the National Institutes of Health? Could anybody be expected to keep a record of the meeting? What they were discussing had criminal implications. Denying knowledge to the public of the life changing potential for vitamin $\mathrm{C}$ based therapies would be impossible to defend. Their protection had to be that many of the links to miraculous vitamin $\mathrm{C}$ effected cures were already in the archive and they were hiding nothing. All that they were doing was to lower the volume. And it seems, that is what they did. The consequences of the order were never expected to be revealed in this way by a computer? Like DNA nobody anticipated computers!

The graph ${ }^{19}$ illustrates control over the number of mentions of Scurvy and "Vitamin C deficiency" in the whole of the PubMed archive aggregated into 5year periods for convenience. If this represents a public mischief, in effect lying about the incidence of scurvy, then the editors and leaders of the profession are culpable. Not only did they suppress knowledge of scurvy but suppression of vitamin $\mathrm{C}$ research is proved (Figure).

The fightback: With limited resources and no help from the Association of Optometrists (AOP) In order to counter the damage done to the public, and provoke a newsworthy development that could not be ignored, the author embarked on publishing books as papers were rejected. He enlisted the help of academics. He engineered his own Fitness to Practise hearing knowing that medicine could not ignore his notices in his practice windows regarding the cure of heart disease. In a meeting with the AOP he said he would fight.

The General Optical Council, was culpable for neglect of its duty after refusing to follow up criminal untruths reported to it by Dr. Mark Hancock ${ }^{20}$ acting on the orders of the decision making group of the 2003 East Hull Primary Health Care Trust (PCT) alleging that the author had illegally used a medical colleague's name without his permission (as if the civil wrong could not have been pursued adequately by the practitioner in question if true). Nor would the AOP help further.

After seven years of suppression and learning from experience that nothing was going to change, the author made a sacrifice to trap the General Optical Council in 2007 and the General Medical Council Pretending to be concerned, he was able to reveal the many untruths of Dr Hancock and Dr. Sue Butler ${ }^{21}$ chief of the Hull NHS at his Fitness To Practise hearing to which these authorities were committed and prayed that he would live long enough to see justice done if and when his name were to be stricken from the register. He boldly insulted the medical profession with notices of heart disease cure! 
Author's Qualifications for challenge to the GOC: He considered that it was a gamble but a risk worth taking. It would be difficult if not impossible, for the Fitness to Practice Committee of the GOC to find him guilty against the public interest, accusing him as someone with an exemplary and unique 55years long record and having saved more UK patients from blindness than ever before. With the unexpected help of the BBC's day long reporting, Thus Optometrists had to dig deep to follow suit and finance $£ 6,500$ American air-puff electronic tonometers. ${ }^{22}$ This had raised UK Optometry as a universal public health measure, reducing the blind on the streets, the associated worry and cost to the community. But the GOC committee ignored all this proven dedicated care at whatever personal financial sacrifice, with no help from the NHS, and the author's lifelong attention to healthcare record. This is described in another paper. From glaucoma to the prevention of CHD is a big step for an Optometrist to take. Seldom does interdisciplinary research result in such profound findings. The long list of the practitioners "Firsts" counted for nothing.

Further papers will deal with the matter in greater detail. Below are examples of what CardioRetinometry can do to change public health

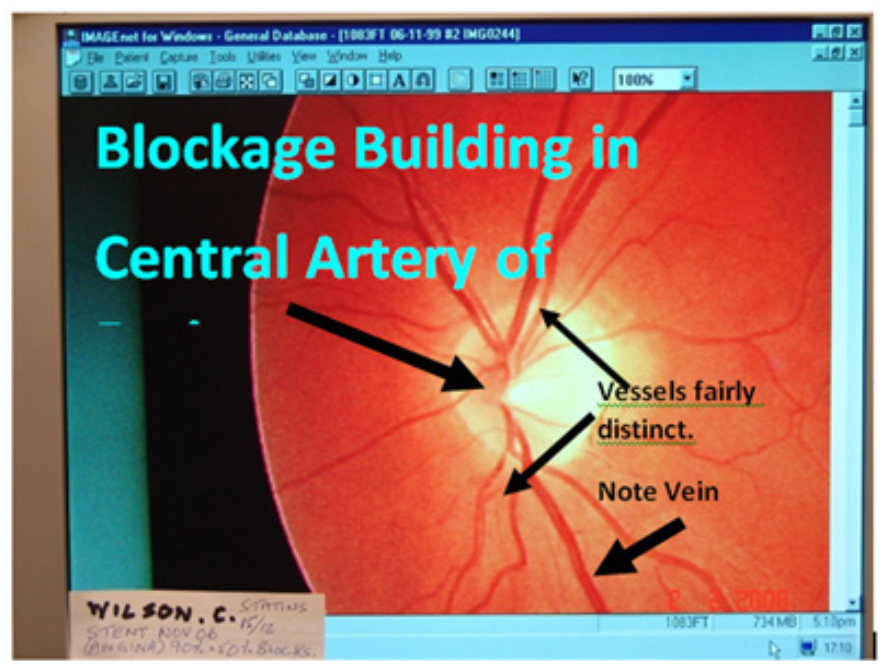

Mr. Wilson above, 6th Nov. 99. Takes a little vitamin $\mathrm{C}$ when he remembers which is not most days.

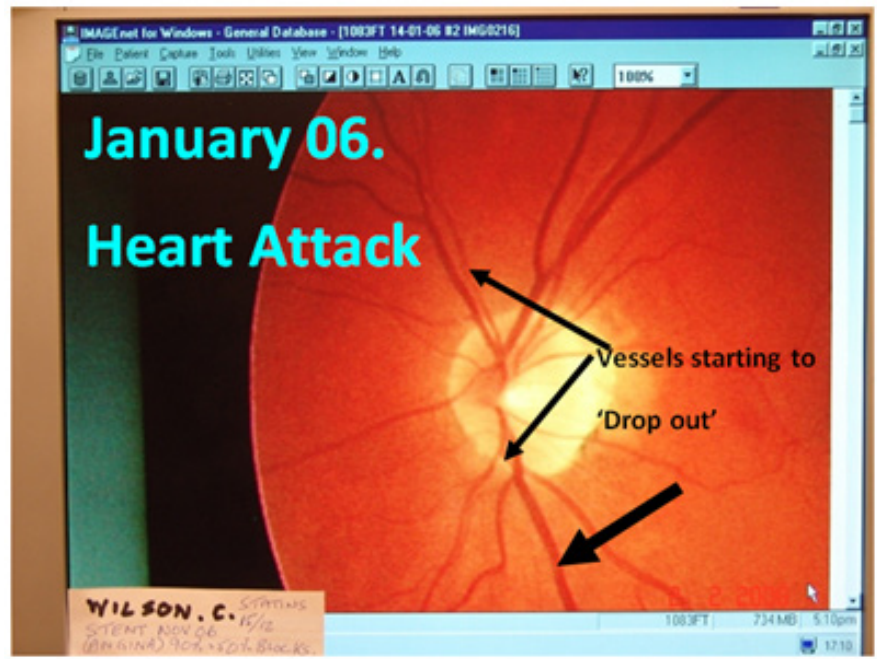

Mr Wilson above 14th Jan. 06. Takes a little vitamin C fails to take more Vit. $\mathrm{C}$ as advised.

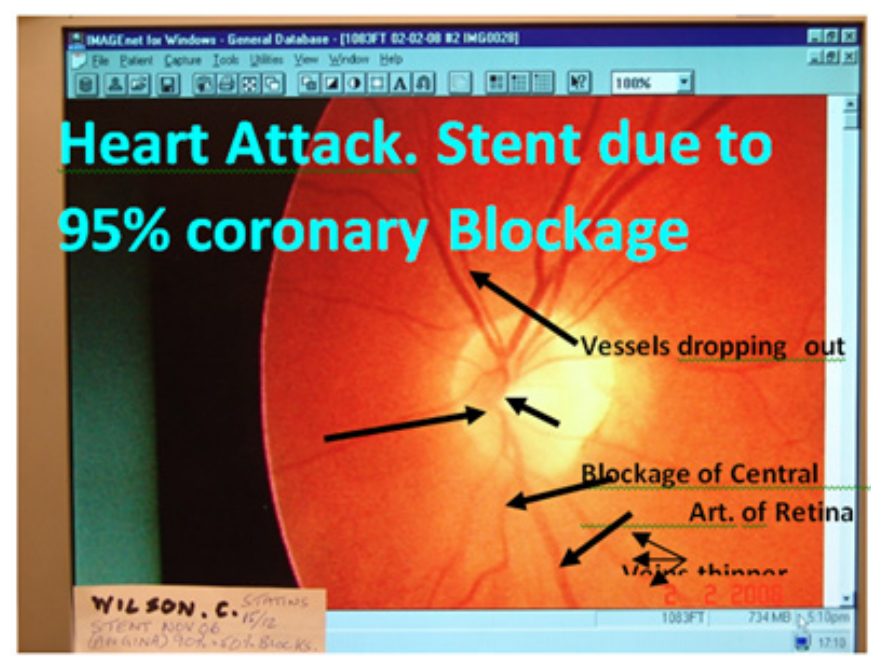

Mr Wilson Above, Age 54. (One of very many Mr C. Wilsons) Confessed he had a Stent Oct 06. "95\% and 50\% blocked." Now on statin +Beta-blocker. Statin is not clearing the blockage. Vitamins ' $\mathrm{C}$ ' $\&$ 'E' could be expected to have prevented this.

The photographs below are a year apart, of a 10-11year old girl whose mother promised to give her vitamin $\mathrm{C}$. The photograph on the Left (the second of the three over the two years) shows vessels after receiving a gram of vitamin $\mathrm{C}$ every day for a whole year. The second photograph (On the Left) shows the arteries after a year of vitamin C. The Right hand photograph after the second year shows how the child's arteries reverted to very near the original poor condition after the mother stopped giving her the vitamin C. Over the two years the change went from ischaemic pale fundus to almost average (poor) and back again to high risk.

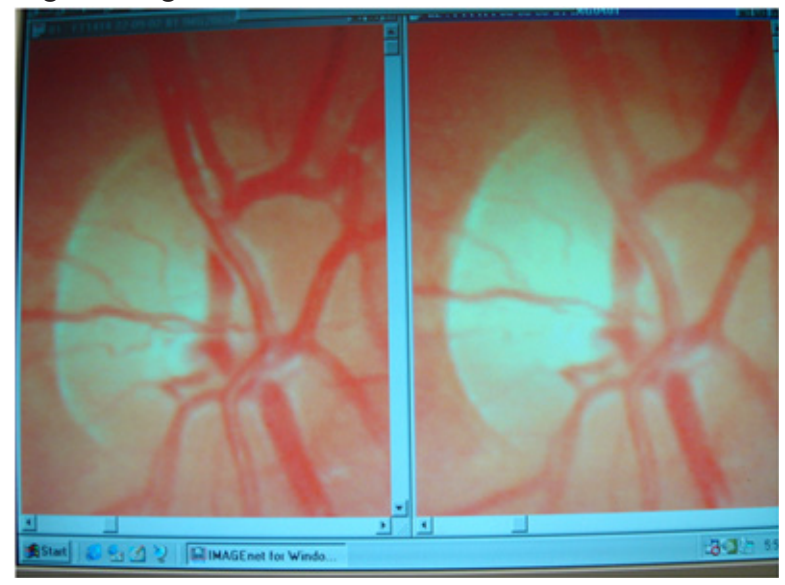

More than the cardiovascular benefits: The National Health Service is the greatest cost on the ${ }^{23}$ public purse not only because of the wanton destruction it wreaks on the cardiovascular system, but in the multitude of occult scurvy related diseases that take up its beds. There is no excuse whatever for, this.

The health of the UK is dependent on China ${ }^{24}$ : No country can boast of having a NHS when that same NHS denies the need for extra vitamin $\mathrm{C}$ and worse, devolves the protection of the best health of its people to a foreign country. The UK is dependent on good relations with China. They could shut off our vitamin $\mathrm{C}$ in an instant even ordering ships to turn round. The situation regarding the suffering of occult scurvy in the UK today is no better than it was for educated people 100 years ago who ate proper food properly grown and always 
fresh before refrigeration. They did not suffer Alzheimer's and cancer on the scale seen today. Nor did they breathe vehicle fumes or suffer medicated water. Fluoride to protect children's teeth is an obvious lie as the figures mount for extractions of baby teeth. Tooth decay is scurvy. Gum disease scurvy defined. But dentists don't want that to be known. They prefer to hide behind fluoride, poisoning the public. Despite puiblic protests even the governments show that they are untruthful.

When pensions are involved the welfare state becomes the public's enemy! Only one small facility in Scotland manufactures vitamin C. Not enough for the UK if everyone were to be told the truth and was advised to take bowel tolerance quantities.

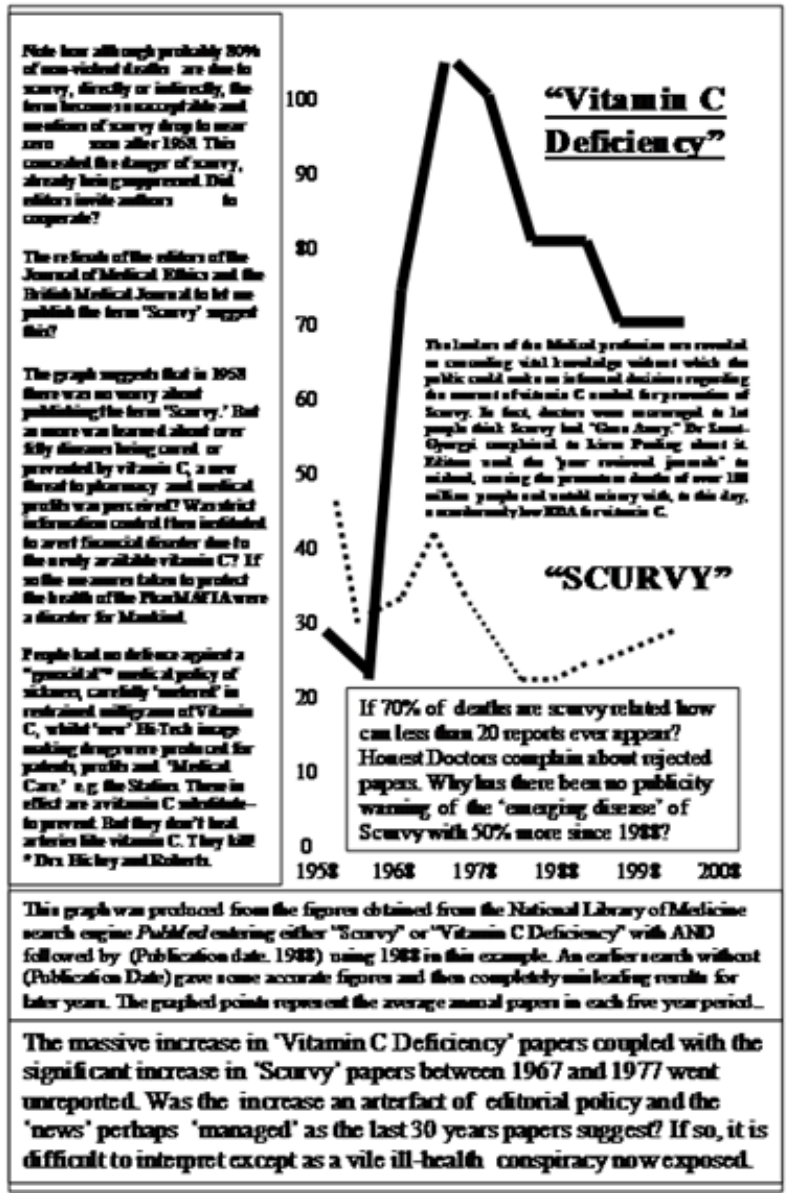

The recent history of medicine: From a personal perspective and the accounts of others - a resumé of less dishonest medicine. The corruption was obviously triggered by vitamin C. Captain Cook $^{25}$ was praised for keeping his crew healthy with fresh food. He didn't lose any of his crew to scurvy unlike Anson ${ }^{26}$ who lost 350 men. Cook's crew wrote sea shanties praising the captain for keeping them well on his long voyages. Doctors of course noted this, and the move to provide lime juice for the Royal Navy after the merchantile marine, was, unaccountably delayed for over 60years by the Admiralty.

Doctors were well aware of the fresh food factor. It was clear, that in a pill, as other deficiency diseases were being identified and prevented, the most prevalent diseases of all might be related to the lack of a still to be discovered vitamin $\mathrm{C}$. There is much evidence that Physicians firmly believed that vitamin $\mathrm{C}$, if and when it was isolated and made available, could well be Nature's magic bullet against disease. By the 20th Century, cures of the many ailments suffered by surviving seamen given little more than lime juice told doctors that much of the call for their services related to self imposed disease from lack of fresh food and particularly fruit and vegetables. Dr Jack Drummond had already named vitamin $\mathrm{C}$ believing when finally isolated, it could bring serious changes as a brief internet search reveals.

A unique, more personal note: In this short paper to introduce the subject, the author trusts his own memory back to 1932. In those days one got the red medicine that was sweet, perhaps had honey and was really a placebo. If one was really ill, one got the green medicine that tasted foul. That was bound to do some good! Whooping cough was a misery that stopped me breathing. The prescription was burning tar in my bedroom. It was filled with smoke from something called a "Cresol Lamp." At four years of age, I wondered if doctors really knew what they were doing? It was terrible.

When my mother gave me hot lemon juice, it was immediate in having some effect on my throat. But she didn't understand vitamin $\mathrm{C}$. When my gums bled brushing my teeth she gave me pink dentifrice. My teeth went rotten during the war as the lady next door succumbed to multiple sclerosis. I helped. Her doctor didn't stay long. He was happy to leave me with her at 15 , to do what I could. I wondered if I really wanted to be a doctor. ${ }^{27}$

My heroes were the great doctors. Semmelweiss, ${ }^{28}$ Lind $^{29}$ and Simpson. ${ }^{30}$ I trusted doctors and eventually at medical school began to worry. My father's friend a doctor who emigrated shortly after the start of the NHS in August 1948, had taken me aside one evening in his surgery a few months after entering Newcastle Medical School. Very seriously and slowly he put his hand on my shoulder, looked into my eyes, and only when he was sure I was paying attention he spoke. "Vitamin C! Absolutely incredible what megadoses can do!" with that he turned and found a cardboard shoebox. He had asked me if I wanted some dissecting practice and I said yes of course. I was due to return to Newcastle the next day. Into my hands he placed a heavy cardboard shoe box that felt cold and damp. Inside, wrapped in greaseproof paper (plastic bags had not arrived) was a perhaps 6 months or more foetus which I believe went into the anatomy department collection. That was my first real lesson in helping people from Dr. Torrance. ${ }^{31}$

Patiently I waited for the physiology professor to tell me about the wonderful things vitamin $\mathrm{C}$ could do. His lecture and information was the opposite of my friend's. I was worried. He was not telling me the truth. Instead I was taught how to lie. I was carefully instructed in the responses to give when asked about supplementary vitamin $\mathrm{C}$ by patients and taught how to mock their beliefs. "The most expensive urine in the street" was a taught response. The contrast was unbelievable. This was supposed to be an honest medical school. I said nothing to my colleagues about my fears. That was in 1949. Nothing more was heard about vitamin $\mathrm{C}$ until health shops started to open in the mid 1950s. I was disillusioned with medicine. Optometry was more attractive and honest. I learned from nutritionist Adelle Davis $^{32}$ in 1966 that all was not well with medicine. Linus Pauling ${ }^{33-35}$ in 1970, and much more in 1985, taught me a great deal. He was honest about vitamin C. Common sense had taught me to consume a fresh tomato every day.

In 1985 I learned that Nobelist Dr. Albert Szent-Gyorgy ${ }^{36}$ had written to Nobelist Dr. Linus Pauling to publish that following his isolation of ascorbic acid, he had noted that "from the beginning, the medical profession misled the public." Continuing to write, SzentGyorgy stated that "if you don't take ascorbic acid with your food you get scurvy, so the medical profession said that if you don't get scurvy you are all right. I think that this is a very grave error. Scurvy 
is not the first sign of the deficiency but a premortal syndrome, and for full health you need much more, very much more." In Pauling's extract from the letter Szent-Gyorgyi concluded with the statement that "What I can tell you is that one can take any amount of ascorbic acid without the least danger."

It must be remembered that in the 1930 s physicians were mostly as poor as the people they served. They rode bicycles to their patients or walked. Few could afford cars. The motor car was a symbol of the status and success of the doctor. They were deeply conscious and embarrassed by this. Doctors then entered a race to have the biggest car. The Rover became a largely agreed vehicle but a surgeon might be expected to have a Bentley. One was embarrassed calling to see a doctor who only had a Morris 8 outside his door. With the motor car, came travel and it became fashionable to have a house in the suburbs from which to travel to a more urban practice. Doctors felt the pressure to live in style and drive bigger cars. That was the pattern before and during WW2. From 1948 doctors were paid whether they saw patients or not in the UK. The major development to change everything was that for the first time pharmacy found it had a customer able to pay its bills with certainty. A golden goose that could lay ever more expensive eggs. Penicillin brought a fortune and the race for more antibiotics followed. The author remembers these events well. At the same time, throughout this period I felt that something was missing. We were constantly being regaled with medical advances, new antibiotics and operations but the life expectancy stayed very much the same for decades. Later I learned that only when people had started taking vitamin $\mathrm{C}$ after Linus Pauling's Vitamin $\mathrm{C}$ and the Common Cold, did the life expectancy start to rise.

The silence should have been broken in years 1948 to 1950 when Dr Frederick R. Klenner started publishing 25 papers on his experiences with his multigram doses of vitamin $\mathrm{C}$, oral and injected, to save lives in many situations. I was in medical school. Klenner should have made headlines round the world. Eventually, frustrated and furious with his colleagues, he published that "The physician would rather allow the patient to die than admit the power of vitamin $\mathrm{C}$ beyond the range of a vitamin." How was that news suppressed? I have never met anybody who was aware of Klenner's amazing discovery except, I can only assume, that it was my good friend Dr Torrance who passed on Klenner's discovery to me before he emigrated. Was the medical profession under orders to keep it quiet? How else can it be explained? In 1981 Forman $^{37}$ complained about medical resistance to inexpensive treatments and in 1993 Ramar et al., ${ }^{39}$ complained about "Scurvy, the forgotten disease." Blatantly, PubMed states "No Abstract Available " for every paper before the last back to and including all Klenner's papers, but allows earlier experimental laboratory research of Jungeblut ${ }^{40}$ that had stimulated Klenner to go to New York to see him.

Truly the history of the great suppression when thus described can only have the effect of a starting the biggest paradigm change in medicine in history if this paper gains the publicity the author wishes. One might confidently expect the public to demand change from cure to prevention, and no more doctors' disease dependency. That is what they signed up for in 1948 expecting a real National Health Service, not the ILL Health Service they got instead.

Physicians must accept the fact that CardioRetinometry has exposed the scam and lies and one doubts that without heads rolling at the top, that, there is going to be final public satisfaction. There will never be any forgiveness whatsoever for the havoc corrupt medicine has wreaked on lives; for the profits on newspaper sales of unnecessary human tragedies, engineered by the corrupt system; pharmacy's megaprofits; the strikes of junior doctors aware that all is not well, and defeating the honest doctors who have appealed to me to help. This catastrophe must end. Forgiveness is impossible. They cannot be forgiven by others for unrelated crimes. They cannot bring the dead back. They cannot resurrects family fortunes.

Then we must study how it was allowed to happen? How could NICE, set up exclusively to protect the public betray its principles and kill People? But in the USA people are asking exactly the same question about the Food and Drugs Authority (FDA) that oppresses people for drug companies' profits, and whose CEOs go through revolving doors into top jobs in pharmacy.

The author exposed NICE in in his BBC broadcast, the transcript being available on the Vitamin C Foundation website. Looking at the early history as described very briefly here, it is clear that research and progress were well on track to solving a huge range of Man's illnesses. Klenner's incredible success brought it, instead to an abrupt halt. He committed suicide. People must have told him privately that he was 100years before his time as they have told me. But I have a thicker skin, and at 88 , I care little what they might try to do to stop me publishing and exposing the rottenness in current medicine and teaching them better, as much as I can, of what they were not allowed to learn in medical school.

\section{Plagiarism}

Is said to be stealing the work of another person. But like me, when one steals the work of dozens it becomes research!

Dr. Irwin Stone's memory goes back to the isolation of vitamin C in 1929 when he was 22 and studying biochemistry. He noted that in 1934, Rineheart ${ }^{38}$ and Mettier found infected guinea pigs deprived of ascorbic acid developed degenerative lesions of the heart valves and muscles. The changes were strikingly similar to those seen in rheumatic fever. Infected guinea pigs maintained with adequate ascorbic acid did not develop these heart lesions. In 1935, Menten et al., ${ }^{41}$ injected sublethal doses of diphtheria toxin into ascorbic acid-deficient guinea pigs and produced myocardial degeneration and arteriosclerosis of the lungs, liver, spleen, and kidneys. When tested later the guinea pigs with acute or chronic scurvy developed inflammation of their heart valves, myocarditis, and occasionally pericarditis. I can do no better at this point than to quote Dr. Stone' $\mathrm{s}^{42}$ words from "The Healing Factor Against Disease."

"As early as 1941 it was suspected that inadequate intake of ascorbic acid was a factor in coronary thrombosis due to impaired collagen production, causing capillary rupture and hemorrhage in the arterial walls. Blood plasma ascorbic acid measurements were made in 455 consecutive adult patients admitted to the Ottawa Civic Hospital over a seven-month period and it was found that 56 percent had subnormal levels (below $0.5 \mathrm{mg} \%$ ) and 81 percent of the coronary patients were in this subnormal range. It was "recommended that patients with coronary artery disease be assured of an adequate vitamin C (ascorbic acid) intake." A 1947 paper showed that inadequate ascorbic acid body levels were not limited to cardiac patients of the lower economic brackets. The scurvy included 556 private patients, of which 123 had organic heart disease. Forty-two percent of all patients, 59 percent of the heart patients, and 70 percent of the coronary thrombotic patients had low plasma levels of ascorbic acid (below $0.5 \mathrm{mg} \%$ ). Sixty-five percent of the coronary group had dangerously low levels $(0.35 \mathrm{mg}$ $\%$ or less). Again it was suggested that ascorbic acid be used as an adjunct to the usual methods of treatment, especially in the longrange care in the post-infarctive period."

Coming more up to date we need to look at some of the conclusions from abstracts of the work of Carl Johnston' $\mathrm{s}^{43-45}$ in Arizona where 
she found that modern medicine in the USA had succeeded in driving down plasma levels to quote her last three papers on this subject.

a. "Cold duration was reduced $59 \%$ in the vitamin $\mathrm{C}$ versus placebo groups $(-3.2$ days; $95 \% \mathrm{CI}-7.0,0.6 ; \mathrm{p}=0.06)$. These data suggest measurable health advantages associated with vitamin $\mathrm{C}$ supplementation in a population with adequate-to-low vitamin $\mathrm{C}$ status."

b. "Since oxidative stress plays a prominent role in immune system activation, regular ingestion of ample amounts of fruits and vegetables $(8+$ servings/d) rich in antioxidant compounds, the polyphenols, carotenoids, and vitamin $\mathrm{C}$ (e.g., citrus, tomatoes, berries, carrots, and greens), lowers inflammatory mediators and risk for chronic disease. Whole grains, legumes, and nuts have also been demonstrated in clinical trials to effectively reduce inflammatory mediators and risk for CVD. Hence, as proclaimed in antiquity, 'let food be thy medicine and medicine be thy food'."

c. "Surprisingly high rates of vitamin $\mathrm{C}$ deficiency and vitamin $\mathrm{C}$ depletion were evident among generally healthy, middle class patients visiting a health care facility for routine health exams, gynaecological exams, and pregnancy exams."

\section{Life extension}

From the "Vox" Antivitamin C website." Pauling fought critics for the rest of his life. In a 1990 redio interview,- four years before his death - Pauling said that people who take vitamin C and other supplements in the "optimum amounts" would live 25 to 35 years longer. "More than that," he said, "they will be free of diseases."

\section{Supporting evidence}

And this is what CardioRetinometry is proving with what appears to be support for Pauling's assertion of surprisingly, up to 35 years life extension. The reasonable claim that $50 \%$ life extension (compared with the three score years and ten) appears to be very reasonable to expect. It was the first of several medical doctors who were contact lens patients who, when let into the news when the author was confident of his findings, who immediately exclaimed "This is Life Extension!" Those "optimal amounts" of which Pauling spoke, were revealed for the first time in history, to be observable precisely in the retinal vasculature and its frequently changing condition as diet improved and worsened, as stresses came and went, as families fought, as jobs were changed and as people accepted the need and were found to thrive on enormously varying daily amounts of vitamin $\mathrm{C}$. The retinal atheroma came back and went again. One could play a very dangerous game with it. Truly little, that doesn't involve fevers, anaphylaxis or cancer, can be so relevant to life and death. Virtually every patient became closely involved in what became an enthralling experience leading to possession of a database of thousands of fine retinal images as above, that are a mine of information regarding the possibilities for development and dissolving of intraluminal and life threatening going back to 1998, unequalled in the entire world. Is it any wonder that pharmaco-medicine attacks CardioRetinometry and tries hard to discredit it. For many in pharmaco-medicine are obviously viewing the situation as a "make or break" life changing matter for them. It is! They will have to practice Prevention and pharmacy will lose a fortune in unwanted, unnecessary illness provoking Toximolecular drugs. All this came from a determination to prevent contact lens patients' infections.

\section{Discussion}

As Hickey and Roberts ${ }^{46}$ stated, "Objectors have very little room for refutation." There are too many retinal photographs showing health returning in those who took extra vitamin $\mathrm{C}$. The sequence of events can be replicated by anyone with a fundus camera and some vitamin C. The only people who will not respond in this way are those who are already taking vitamin $\mathrm{C}$ at bowel tolerance for sufficient time, or the very rare ones who will live to over 100 without ever taking a supplement. Is it possible that with this tool to closely monitor the heart every six months, that in addition to the degenerative diseases of the cardiovascular system, stroke, aneurysm thrombosis, haemorrhage, peripheral circulatory failure, kidney failure, neurodegeneration matching the ischaemia of the retina to the early "transient" ischaemia attacks we expect with age and more will assuredly lead to enhanced life extension. Pauling surmised an extra 30 to $35 y$ years from his own knowledge and expectations? 50\% life extension from any age of entry according to the life insurance actuarial tables would seem to predict the end of pensions as presently calculated and the author published a warning about this ten years ago, "Pension Funds To Crash!" when the trend became obvious. How much money is corruption in medicine, pharmacy and the NHS costing in cash alone?

Levy in his "Stop America's \#1 Killer" believes coronary arterial heart disease can be stopped. So does Matthias Rath. He says so in his “Why Animals Don't Get Heart Attacks, But People Do." (P 39) From this research the Author is convinced that Pauling, supported by Rath, was right Willis agreed - he started X-Ray angiography and vitamin C usage. Dr Kenneth Walker MD (writing under the Canadian medical Assnenforced pen name he chose of Dr W. Gifford-Jones MD,) in his many newspaper columns in 100 newspapers (But not in the USA!) entirely agrees and says Dr Bush's Historic Discovery is Worthy of the Nobel Prize. "Medicine dare not let that happen for fear of the publicity it would bring to vitamin C's benefits shown in 700 Vitamin Secrets (and 1000 not so secret for doctors!) a deliberately insulting title.

The NHS threats, the doctors courting prison sentences to keep it secret, all provide the evidence for a massive, the most massive, fraud of any kind in human history, having been perpetrated by the Pharmaco-Medical business with disease. Nobody can calculate the millions whose lives have been wrecked. Nobody can calculate how many families incomes have been destroyed. Nobody can calculate the millions of bereavements, loss to industry, science, even ironically, medicine, The ultimate sacrifice has been paid even by most doctors it seems, who could instead of a premature death, have earned over $£ 365,000$ with only 1,000 registrants, paying 99pence per day since 2005 . If a grateful public was prepared to pay an Optometrist $£ 450 / y$, wouldn't they pay a more highly qualified physician more? I would expect them to be paid $50 \%$ more, most doctors could expect grateful registrants to double or treble that in more affluent areas.

\section{Conclusion}

\section{A massive financial loss to physicians}

This paper closes with hard facts and figures, this Optometrist found it easy to obtain $£ 450$ /year for heart care CardioRetinometry. That is over $£ 1$ a day. For just over 1,000 registrants that equals $£ 500,000 / \mathrm{yr}$ which means a massive loss to virtually every doctor in the UK by allowing themselves to be suckered into believing the blandishments of the NHS and Pharmacy and medical leaders in the GMC. Is the frank language appropriate? The late Dr. Russel Smith ${ }^{47}$ on the subject of cholesterol and cholesterol lowering drugs, stated "The fraud is so blatant and so pervasive, that it was considered necessary to to take some liberties with the usual staid rhetoric of a scientific review and inject stronger language to emphasize the problem". The research has been started and sufficient proved despite 
no help from any funding source even denying use of public funds donated for the purpose. Honest physicians have started to accept this and take the course. Other Physicians must now be compelled to learn what was held back from them in medical school and qualify DCardioRet as soon as possible. The first medical doctor is expected to qualify in May 2017 with more due in 2018.

\section{Conflicts of interest}

The author heads the Faculty of CardioRetinometry of the internationally accredited Cosmopolitan International University that is required to provide the education this paper identifies as missing from and falsified within the curriculum of Western medical schools. $\mathrm{He}$ has an interest in the books, educational materials, the teaching and image evaluation provided by the Institute of CardioRetinometry.

\section{Acknowledgments}

None.

\section{Funding}

None.

\section{References}

1. Ben Goldacre. Rational Skepticism Website clearly anti-Vitamin C gratuitously describes CardioRetinometry as Pseudo-Science. Discussed matter with many years ago when first discovered who refused to take down his offensive comments. 2004

2. Hickey, Roberts. Ridiculous Dietary Allowance Lulu.com, North Carolina, USA. 2005. p. 1-151.

3. Klenner FR. The vitamin and massage treatment for acute poliomyelitis. South Med Surg. 1952;114(8):194-197.

4. Klenner FR. Massive doses of vitamin C and the virus diseases. South Med Surg. 1951;113(4):101-107.

5. Klenner FR. Fatigue, normal and pathlogical, with special consideration f myasthenia gravis and multiple sclerosis. South Med Surg. 1949;111(9):273-277.

6. Klenner FR. The treatment of poliomyelitis and other virus diseases with vitamin C. South Med Surg. 1949;111(7):209-214.

7. Klenner FR. Virus pneumonia and its treatment with vitamin C. South Med Surg. 1948;110(2):36-38.

8. Sabin AB. Vitamin $\mathrm{C}$ in relation to experimental poliomyelitis. $J$ Exp Med. 1939;69(4):507-516.

9. Smith Lendon H. Clinical Gide to the Use of Vitamin C. Life Sciences Pr. 1991.

10. Paterson JC. Some factors in the causation of intimal haemorrhage and in the precipitation of coronary thrombi. Can Med Assoc J. 1941;44(2):114-120.

11. Willis GC. The reversibility of atherosclerosis. Can Med Assoc $J$. 1957;77(2):106-108.

12. Willis GC. The influence of ascorbic acid upon the liver. Can Med Assoc J. 1957;76(12):1044-1048.

13. Bolker HI, Fishman S, Heard RD, et al. The incorporation of acetate 1-C14 into cholesterol and fatty acids by surviving tissues of normal and scorbutic Guinea pigs. J Exp Med. 1956; 103(2):199-205.

14. Willis G, Fishman S. Ascorbic acid content of human arterial tissue. Can Med Assoc J. 1995;72(7):500-503.

15. Willis GC, Light AW, Gow WS. Serial arteriography in atherosclerosis. Can Med Assoc J. 1954;71(6):562-568.
16. Willis GC. Localizing factors in atherosclerosis. Can Med Assoc J. $1954 ; 70(1): 1-9$

17. Willis GC. An experimental study of the intimal ground substance in atherosclerosis. Can Med Assoc J. 1953;69(1):17-22.

18. Willis GC. The frequency, pathogenesis and significance of intimal haemorrhage. Can Med Assoc J. 1952;67(6):644-648

19. Sydney J Bush. 700 Vitamin C Secrets. Direct Print on Demand Ltd, Brixworth, UK. 2010. p.448.

20. Fitness to Practice Hearing.

21. Sue Butler itness to Practise Hearing.

22. Bernard Grolman. AO Co Tonometer, UK. 1975.

23. Cost of NHS. Full data must be sought on the Internet. So many aspects are involved some vital, some simply opportunities for employment. A proper cost analysis of effectively treating the listed diseases and many more too numerous to list, should be carried out without delay at the same time as organizing further training of doctors for the Doctorate in Cardio Retinometry.

24. China manufacturing Vit C. Prices shot up worldwide when the Olympic Games required the temporary closure of two of the factories polluting the river.

25. James Cook (1770) First voyage of James Cook.

26. Admiral George Anson circumnavigation q740-1744 lost over 1,600 men of $1854 a$

27. Semmelweiss. Ignaz first doctor to demand disinfection of hands before delivering babies. Went mad in an asylum when his colleagues refused to take notice. (Like Dr Klenner committed suicide when his colleagues suppressed all his wonderful cures)

28. Lind James. (1716).

29. Simpson anaesthetics.

30. Torrance Dr Stanley. Honest General Practitione. 1949.

31. Davis, Adelle Let's Get Well. 1965.

32. Pauling, Linus. Vitamin C and the Common Cold. 1970.

33. Pauling Linus. How To Live Longer And Feel Better. (Avon) and later Oregon State Univ. 1985.

34. Vox Antivitamin C website) Pauling fought critics for the rest of his life. In an interviewfour years before his death -Pauling said that people who take vitamin $\mathrm{C}$ and other supplements in the "optimum amounts" would live 25 to 35 years longer. "More than that," he said, "they will be free of diseases." Quoted by Heather Mangieri, a nutritionist working with the Academy of Nutrition and Dietetics.

35. Szent-Gyorgyi. Isolation of vitamin C. Pp 6-7 How to Lice Longer and Feel Better. Linus Pauling. 1937;1985.

36. Forman R. Medical resistance to innovation. Med Hypotheses. 1981;7(8):1009-1017.

37. Rinehart JF, Mettier SR. The heart valves and muscle in experimental scurvy with superimposed infection. Am J Pathol . 1934;10:61-79.

38. Ramar S, Sivaramakrishnan V, Manoharan K. Scurvy - a forgotten disease. Arch Phys Med Rehabil . 1993;74(1):92-95.

39. Jungeblut CW. A further contribution to vitamin C therapy in experimental poliomyelitis. $J$ Exp Med. 1939;70(3):315-332.

40. Michaelis Menten Determination of vitamin C needs, In Situ Kinetics of vitamin C. A biochemical testing with 11 fundamental complications.

41. Stone, Irwin. The healing Factor Against Disease. An important book. 1972. 
42. Johnston CS, Barkyoumb GM, Schumacher SS. Vitamin C supplementation slightly improves physical activity levels and reduces cold incidence in men with marginal vitamin $\mathrm{C}$ status: a randomized controlled trial. Nutrients. 2014;6(7):2572-2583.

43. Johnston CS. Functional Foods as Modifiers of Cardiovascular Disease Am J Lifestyle Med. 2009;3(1 Suppl):39S-43S.

44. Johnston CS, Thompson LL. Vitamin C status of an outpatient population. J Am Coll Nutr. 1998;17(4):366-370.
45. Hickey and Roberts. "RDA. Ridiculous Dietary Allowance" p111 ( in 107-111). 2004.

46. Smith, Dr. Russell, Experimental psychologist cooperated with Dr Edward Pinckney, editor of four medical journals. Smith presented the evidence in two large scientific reviews containing 700 pages and 3,000 references exposig the cholesterol fraud. 